\title{
Infographics and narrative: exploring concepts
}

\author{
Rosângela Vieira, \\ Paulo Cunha, \\ Eva Rolim
}

\section{INTRODUCTION}

Our study had as a starting point the inquiry into the state of the art of infographics within the Information Design field. Our purpose was to determine what research on the topic is being carried out in Brazil, since it has been, with the purpose of determining what is being researched about this topic, in Brazil, since it has presented itself in the field with some recurrence. Subsequently, it was broadened in order to analyse the existing relation between infographics and narrative, once the word 'Narrative' cannot be treated as one of easy comprehension, as states Bal (1997), in other words, it cannot be used under the assumption that every person will understand it in the same way, requiring closer attention to the way it should be used.

To observe the relation between the infographics and the narrative, 28 articles were selected, among those published in the Infodesign Journal between the years of 2011 and 2017; and in the CIDI Proceedings of 2011, 2013 and 2015. Within this group, 12 did not make any mention to the word narrative and 16 cited the term but did not present any definition or concept, in order to give the reader an understanding of which line of thought was being approached in the text when the it was mentioned.

When it comes to figures, considering the two means of publication within the field of Information Design, it was noted that in 2011, out of 4 articles, only 1 used the term narrative. In 2012 there was only 1 publication that made mention to the word time-space narrative graphic. Five articles were published in 2013, 2 of which cited the expression; whilst in 2014, of the 4 articles present, 3 of them used the term narrative. In 2015, out of the 7 articles published, 6 mentioned it; in 2016 the word narrative occurs in only one quotation; and in 2017, out of 7 articles about infographics, 3 mentioned the term narrative. It is curious 
to notice that the 7 articles from 2017 correspond to v.4, No $13^{1}$ of Revista Infodesign, an issue entirely dedicated to the theme of Complex information and Infographics.

These results suggest that there is a certain interest about the subject of infographics and narrative within the Information Design field. It can also be said that the term narrative was not used with a clear definition, which is unsettling, if we consider that "although everyone has a general idea of what narrative texts are, it is certainly not always easy to decide whether or not a given text should be considered narrative, partly or wholly" (Bal, 1997, p. 3).

This observation becomes intriguing when we raise questions such as: Which meaning does the term narrative incorporate? When used alongside the word infographics, which relation can we establish? As we detected this gap, we chose to tackle this issue, by bringing into the discussion the authors who, in some way, could contribute to the understanding of what an infographic is; as well as authors who would collaborate on the comprehension of what narrative is, so that we can then create a correlation between the two.

To that effect, the objective of this article is to contribute to the discussions within the field of design, pertinent to the theme of narrative, having as its object of study the infographic. The choice of infographics was influenced as much for their quality of presenting complex information in a clearer way, drawing near Information Design, as for the hope that the debate over the object of study does not become limited solely to the graphic aspects, as we often see.

The results gathered in this article reveal that there is no consensus as to what a narrative applied to the infographic is, making the understanding of it within the field of Information Design more difficult. Considering the diversity of existing terms and definitions, from several authors and their trends, it becomes crucial to create a parameter to generate more unambiguous discussions.

Thus, for a better comprehension of the concepts, some definitions about the infographics will be presented, to allow better understanding of the object of study, followed by the concept of narrative taken from different areas. Based on these definitions, we will examine how the terms were used in the articles selected within the field of Information Design.

1 This volume can be accessed through the URL https://www.infodesign.org.br/infodesign/issue/view/39 


\section{BRIEF DEFINITIONS FOR AN UNDERSTANDING OF THE INFOGRAPHICS}

In order to know better the object of study and have a few parameters to understand the breadth of this word, we present here some definitions of what an infographic is, since it is possible to find a great variety of descriptions for the term in the literature about the theme.

Many are the authors that attempt to explain the meaning of infographic. As the aim of this text is not to discuss whether the concept is right or wrong, but merely to display to the reader a few definitions that may aid them in the understanding of the relations which we intend to create here. Hence, we elected the interpretation proposed by Lima (2009), seeing that he stands out in the references found in the chosen articles; by (2005) and Lucas (2011), because they presented a definition for the concept considering the perspective of various authors; as well as Lankow, Ritchie and Crooks (2012), for posing the term "editorial infographics" and Rajamanickam (2005), for bringing a view of the object that goes beyond its graphics aspects.

Having said that, we noted that some of the articles analysed used as reference the definition proposed by Lima (2009), who in his master's degree thesis defines the term infographics as "uma peça gráfica que utiliza simultaneamente a linguagem verbal gráfica, esquemática e pictórica voltada prioritariamente à explicação de algum fenômeno" (Lima, 2009, p. 23)². In addition to that, encompassing a bit more, the author presents a definition for journalistic infographics, from the viewpoint of journalistic design, in an attempt to make it clear that the infographic differs from traditional illustration in the way it relates to the text, for it would not be subordinated to a subject, but acting as an autonomous source of information, as he defines:

Um tipo de matéria jornalística onde o texto e a iconografia são interdependentes e a estratégia de leitura pode se desenvolver de forma não-linear, que se diferencia da iconografia tradicional pela possibilidade de se comportar como a fonte principal de informação na página (Lima, 2009, p. 26). ${ }^{3}$

2 "A graphic piece that simultaneously uses the verbal graphic, schematic and pictorial language primarily meant to the explanation of some event."

3 "A type of journalistic piece where the text and the iconography are interdependent, and the reading strategy may develop in a non-linear way, which differs from traditional iconography through the possibility of performing as the main source of information on the page." 
On the other hand, Ribas (2005) and Lucas (2011) agree that there is no consensus for the term infographics. In his article, Ribas (2005) tries to delimit the concept of infographics from authors belonging to the field of journalism, to establish differences and to allow for a clearer comprehension of the term. The definition posed by her states:

A infografia tem a função de facilitar a comunicação, ampliar o potencial de compreensão pelos leitores, permitir uma visão geral dos acontecimentos e detalhar informações menos familiares ao público, tendo como conteúdo explicações em diversos níveis de complexidade, apresentações de fatos ou acontecimentos, informações de funcionamento, descrições de processos. Esta definição, que consideramos a essência do conceito, apesar das diferenças, está contida no discurso de diversos autores do campo do jornalismo (RIBAS, 2005, p. 16) ${ }^{4}$.

Lucas (2011) suggests defining infographics being based on criteria from schematic language and in graphic-visual considerations. In his thesis, the author defines infographics trying to understand the term stemming from authors that explain it not only in the Portuguese language but also in English, Spanish, and French. Moreover, he establishes criteria that both define what an infographic is and also differentiates it from other graphic visual representations (RGV). Thus, his definition says:

A infografia é um tipo de RGV mista que tende a utilizar hibridamente outros recursos visuais (os infogramas) tendo por base visual um diagrama preparado a partir do esboço de um jornalista, pelo fato de ela ser o produto da combinação desenhada a posteriori entre o esquema (lógico-relacional) e a esquematização (visual-referencial), e totalmente suscetível de mudança de conteúdo, significação e sentido em casos de alteração nos níveis dos sintagmas e da forma da expressão (Lucas, 2011, p. 249). ${ }^{5}$

4 "Infographics have the role of facilitating communication, broadening the potential for comprehension by the readers, allowing a general view of the events and detailing information which are less familiar to the public, having as content explanations in several levels of complexity, presentation of facts or events, operating instructions, description of processes. This definition, which we regard as the essence of the concept, despite the differences, appears in the discourse of several authors from the journalism field."

5 "Infographics is a type of mixed RGV which tends to utilize in a hybrid way other visual resources (infographics) having as its visual basis a diagram prepared from the outline by a journalist, due to the fact that it is the product of the combination (designed after the event) between the logical relational schema and the layout (visual referential), and completely susceptible to change in content, signification and meaning 
What stands out in Lucas's (2011) proposition is his concern in setting infographics apart from other types of graphic visual representations (RGV), which would be interesting to investigate more appropriately in another research, to confirm whether these differentiations, and even the RGV configurations, can bring (or not) some contribution to the field of design.

For Lankow, Ritchie and Crooks (2012) the term infographics is an abbreviation for "information graphic." Besides, they claim that some use the term to refer to the type of format that has been widely adopted by this application, which is characterized for the use of illustration, wide and long typography, and vertical orientation to display a variety of facts. This characterization is referred to by the authors as "editorial infographics." The authors also explain that the infographic uses visual clues to communicate information and that they do not need to hold a certain amount of data, possess a certain complexity or present certain levels of analysis; but they can be as simple as a street sign that can provide you an indication or have a higher level of complexity.

According to Rajamanickam $(2005$, p. 2) "infographic" is the same as "information graphic," in agreement to what he quotes, "In the attention scarce world of today, information graphics (or infographics) have taken the media and communications industries by storm." For the author, building a visual representation of a piece of information means to filter the information in order to establish connections between them, observe if there are patterns, and then represent them in such a way that the recipient is able to construct an understanding with meaning, in other words, it goes beyond the issues on the graphics aspects of composition, striving to give the reader clear understanding of the content it intends to convey. The author deems that "information graphic reveals the hidden, explain the complex and illuminate the obscure" (Rajamanickam, 2005, p. 2).

Faced with the definitions presented, it can be noted that they emerge in diverse ways, coming from the perspective of each author. Ribas (2005) approaches his concept based on the authors from the field of journalism; Lucas (2011) proposes the definition of infographics as a graphic visual representation which has as support a diagram posed by a journalist; Rajamanickam (2005), who while in agreement with Lankow, Ritchie e Crooks (2012) that "infographic" is the same as "information graphic", grants that an infographic goes beyond the graphic aspects and must offer the reader clear understanding of the message; and Lima (2009), who constructed his concept taking in consideration the different resources of graphic language.

when there is alteration in the syntagma levels and in the expression form.” 
Therefore, in consonance to what was presented, it is possible to conclude that in the literature, not only there is no consensus over the term infographics, but also there is no accordance as for the definition of infographics since the concepts - at least the ones presented here - diverge. Furthermore, there are the problems in the translation from English to Portuguese and from Portuguese to English, which widen this ambiguity. According to Ribas (2005, p. 5):

No inglês, graphics é diagram, mas diagram, não é o mesmo que chart ou graph, as traduções corretas para 'gráfico', em português. Por outro lado, chart e graph podem ser diagrams, porém, o contrário não ocorre, ou seja, diagram não é o mesmo que chart ou graph. Se fizermos, portanto, a tradução correta do inglês para o português identificaremos que 'diagrama' não é sinônimo de 'gráfico', embora em nossa língua o seja. Isto nos permite sugerir que a tradução mais correta para a origem do conceito de 'infográfico' ou 'infografia', infographics, seja 'diagrama informativo'. ${ }^{6}$

Additionally, it is necessary to remember that there are authors who consider infographics as a technique, a tool, a language, or yet, a format, according to Lankow, Ritchie and Crooks (2012). Taking this lack of boundaries for the term, it is natural, therefore, that designers also make use of the variety of definitions, as a reflection of the literature itself, which hinders the understanding of what an infographic is within the field of design.

\section{NARRATIVE - A FEW CONCEPTS}

In the introduction of Routledge Encyclopedia of Narrative Theory, the authors Herman, Jahn and Ryan (2005, p. ix) comment that "The past several decades have seen an explosion of interest in narrative, with this multifaceted object of inquiry becoming a central concern in a wide range of disciplinary fields and research contexts." According to them, the studies regarding narrative gained strength in France, in the mid-sixties, with the development of the structuring theories of narrative, and since then, they have been attracting the interest of

6 "In English, graphics is diagram, but diagram is not the same as chart or graph, the proper translations for 'gráfico' into Portuguese. In contrast, chart and graph can be diagrams, and yet the opposite is not true. In other words, the diagram is not the same as chart or graph. Hence, if we accurately translate from English into Portuguese, we will notice that 'diagrama' is not a synonym of 'gráfico,' even know in our language it is so. This enables us to suggest that the most accurate translation for the origin of the concept of 'infographic' or 'infographics' (infographics) is 'informative diagram.'” 
many subjects, such as sociolinguistics, discourse analysis, communication studies, literary theory and philosophy, cognitive and social psychology, ethnography, sociology, media studies, artificial intelligence, amongst others.

Thus, given the vast diversity of the concepts about narrative, coming from distinct areas, and the contexts of each field, we will present some definitions intending to aid the comprehension of the meanings in the usage of the term narrative in the articles analyzed. Consequently, the goal here is only to bring the reader some definitions so that they can understand this amplitude.

Starting with the field of Semiotics, Greimas and Courtés (2013, p. 327) in their Semiotics Dictionary, define the term narrative "as that used to designate a narrative discourse of figurative nature, with characters that perform actions." This concept has some basis in Vladimir Propp, author of the book Morphology of the folktale (1928), who defines the function as "the act of a character" (Herman, Jahn and Ryan, 2005), that is, actions that a character fulfills in the story.

According to Reis and Lopes, in their Dicionário de Teoria da Narrativa, the term can be understood in several ways:

Narrativa enquanto enunciado, narrativa como conjunto de conteúdos representados por esse enunciado, narrativa como ato de os relatar (cf. Genette, 1972 , p. 71-2) e ainda narrativa como modo, termo de uma tríade de "universais" (lírica, narrativa e drama) que, desde a Antiguidade e não sem hesitações e oscilações, tem sido adotada por diversos teorizadores (...) (REIS and LOPES, 1988, p. 66). ${ }^{7}$

For the authors, the last definition will be of interest, the one which considers narrative as a literary form, once the other definitions can be contemplated by other terms such as narrations and story, or by concepts such as discourse. As Mieke Bal (1997, p.5) writes:

"A narrative text is a text in which an agent relates ('tells') a story in a particular medium, such as language, imagery, sound, buildings, or a combination thereof. A story is a fabula that is presented in a particular manner. A fabula is a series of logically and chronologically related events that are

\footnotetext{
7 "Narrative as wording, narrative as a set of contents represented by this wording, narrative as act of reporting them (cf. Genette, 1972, p.71-2) and even narrative as manner, term which belongs to a triad of "universals" (lyrical, epical and dramatic) which, since Ancient times and not without hesitations and oscillations, has been adopted by several theoreticians (...)".
} 
caused or experienced by actors. An event is a transition from one state to another state. Actors are agents that perform actions. They are not necessarily human. To act is defined here as to cause or to experience an event.”

Bal furthermore comments that to state that narrative text is one in which a story is told, implies that the text is not identical to the story since different texts can tell the same story, some being more literary than others. She exemplifies declaring that "Everyone in Europe is familiar with the story of Tom Thumb. However, not everyone has read that story in the same text. Where are different versions; in other words, there are different texts in which that same story is related" (BAL, 1997, p. 5).

In Narratology: the form and functioning of narrative, Prince (1982, p. 4), puts that "narrative is the representation of at least two real or fictive events or situations in a time sequence, neither of which, presupposes or entails the other". Nonetheless, it is necessary to indicate that for Prince, even though the representation may be connected to time dimension, not all of them constitute a narrative. In addition to that, though many things can take time, its representations do not necessarily comprise a narrative. The author quotes the following example:

A fight can take a few minutes, and a trip can take a few hours yet neither

(5) There was a fight yesterday

nor

(6) It was a beautiful trip

constitute narratives: they do not represent the fight or the trip as a series of events but as one event. (PRINCE, 1982, p. 2)

In the field of Narrative Film, Aumont (2012, p. 106) defines that "a narrativa é o enunciado em sua materialidade, o texto narrativo que se encarrega da história a ser contada. (...) No cinema, compreende as imagens, palavras, menções escritas, ruídos e música..." ${ }^{8}$. As stated by the author, these elements increase even more the complexity of the film narrative, since elements without narrative value, such as the music, becomes a narrative element of the text through its presence alongside the image and dialogues.

Alternatively, in the Dicionário Teórico e Crítico de Cinema, Aumont and Marie (2003, p. 209) present the definition of narrative proposed by the French structuralist Gerard Genette, who points out three possible meanings for the word narrative:

8 "the narrative is the wording in its materiality, the narrative text is in charge of the story to be told. (...) In film, it encompasses the images, words, written mentions, noises, and music...” 
(...) "O enunciado narrativo que assegura a relação de um acontecimento ou de uma série de acontecimentos"; "a sucessão de acontecimentos reais ou fictícios que são objetos desse discurso, e suas diversas relações de encadeamento, de oposição, de repetição etc."; enfim, "não mais [o acontecimento] que se conta, e sim aquele que consiste no fato de alguém contar alguma coisa". Genette e a maioria de seus sucessores concordam em restringir o emprego da palavra à primeira dessas significações (o segundo sentido corresponde então à história; o terceiro, à narração). ${ }^{9}$

Herewith, the author poses that in the works of film narratology, the idea of narrative acquired a few characteristics that define it, which are, in short: a narrative is closed, having a beginning, a middle and an end; it tells a story; someone or a semi abstract institution produce it; and its narrative unit is the event.

In the field of literature, Gancho $(2006$, p. 67) defines the narrative as a text in prose in which a story is told. It, in turn, does not exist without the facts, which are experienced by the characters, in a specific time and place. The author highlights that to be prose fiction it is required the presence of a narrator, who will be the organizing element of all the components and the middlemen between the story (the what is narrated) and the author, and between what is narrated and the reader.

In Linguistics, we underscore the contribution by Trask (2004, p. 204) towards the definition of the term as:

Narrativa é um texto que conta uma história. Uma narrativa difere da maioria dos outros tipos de textos pelo fato de narrar uma série conexa de eventos, reais ou fictícios, de maneira mais ou menos ordenada. Além dos tipos conhecidos de narrativas escritas, tais como os livros de histórias e os romances, existem narrativas orais, isto é, histórias que se contam falando. ${ }^{10}$

9 “(...) "The narrative wording which assures the relationship of an event or a series of events"; "the succession of real or fictitious events which are object of this discourse, and its diverse relationships of enchainment, of opposition, of repetition etc.", once "no longer [the event] is told, but that in which consists the fact of someone telling something." Genette and the majority of his successors agree about restricting the usage of the word to the first of these significations (the second meaning corresponds then to the story; the third, to the narration)."

10 "Narrative is a text which tells a story. A narrative differs from most other types of text for the fact it narrates a related series of events, real or fictitious, in a mostly orderly manner. Besides the well-known written narratives, such as storybooks and novels, there are oral narratives, that is, stories that are told through speech." 
The definition presented by Trask resembles the definition proposed by Gancho in the sense that it tells a story. Taking the later as a basis, when comparing the concepts as mentioned earlier, we can find some points in common. For instance, Gancho states that the narrative is a text that tells a story (similarly to Bal, Trask e Aumont and Marie), where the facts, which we may call events or happenings (as proposed by Prince e Aumont and Marie), are experienced by characters (as put by Greimas and Courtés), in a specific time (according to Prince) and place.

Evidently, this is not an attempt to create a general definition for the term narrative, but merely to show that despite the distinct areas, we are able to find points that intersect and permeate the authors' definitions and that, in some way, it is interesting to observe how they treat the terms which appear to have singular definitions in their areas.

Therefore, to use the word narrative without having a clear idea of what the word is representing within the text is to provide the reader the possibility of diverse interpretations, which hinder its understanding, seeing that if there are different definitions depending on the field of study, which of them is being used by the designer when they relate it to infographics? Also, if we consider that there is no difficulty in the comprehension of the term, would it be possible to declare that the definition of narrative has met accordance among designers?

\section{METHODOLOGY}

The methodology procedures adopted in the research took on the division in two phases. Phase 1 aimed at identifying what were the articles in the field of Information Design in Brazil discussing regarding infographics. With the results of this first phase, we were able to notice that there was a gap in the studies about the topic which approached it in a more specific way the area of narrative.

Thus, a need to investigate the selected articles emerged, to understand how the topic of the narrative was being discussed alongside infographics. This moment comprised the objective of phase 2 .

\section{Research question and topic}

In phase 1, the initial research question was steered from the question 'What does recent research in Brazil discuss regarding infographics in Information Design?'. From this starting point, the search in the research bases was lead by the topic INFOGRAPHICS.

The choice for analyzing Infographics, which make use of images, illustrations, and icons, in addition to texts, animations, interactivity, happened because 
they have the objective of presenting complex information in a more precise way, coming closer to Information Design.

In phase 2 the guiding question was 'How do the articles about Infographics, in the field of Information Design, treat the term narrative?'. Based on this question, the topic used for the search was the word NARRATIVE.

\section{Research Bases}

Since the purpose of the investigation was to examine the panorama of recent research carried out and published in the field of Information Design in Brazil, the eye was directed towards the selected articles, starting from 2011 in the Revista InfoDesign - Revista Brasileira de Design da Informação (Brazilian Journal of Information Design) and the CIDI - Congresso Internacional de Design da Informação (Information Design International Conference) Proceedings. Even though the 8th CIDI took place in the year of 2017, it was not included in the research bases (Table 1), for the Proceedings of the conference had not been published at the time this text was written.

It is important to mark that the research bases were the same for both phase 1 and phase 2 .

\begin{tabular}{|c|c|c|}
\hline \multicolumn{3}{|c|}{ Research Bases } \\
\hline Year & Revista Infodesign & CIDI Annals \\
\hline 2011 & v. $8 \mathrm{~N}^{0} .1 ; \mathrm{N}^{0} .2 ; \mathrm{N}^{0} .3$ & $5^{\text {th }}$ CIDI Annals \\
\hline 2012 & v. $9 \mathrm{~N}^{0} .1 ; \mathrm{N}^{0} .2 ; \mathrm{N}^{0} .3$ & --- \\
\hline 2013 & v. $10 \mathrm{~N}^{0} .1 ; \mathrm{N}^{0} .2 ; \mathrm{N}^{0} .3$ & $6^{\text {th }}$ CIDI Annals \\
\hline 2014 & v. $11 \mathrm{~N}^{0} .1 ; \mathrm{N}^{0} .2 ; \mathrm{N}^{0} .3$ & --- \\
\hline 2015 & v. $12 \mathrm{~N}^{0} .1 ; \mathrm{N}^{0} .2 ; \mathrm{N}^{0} .3$ & $7^{\text {th }} \mathrm{CIDI}$ Annals \\
\hline 2016 & $\begin{array}{l}\text { v. } 13 \mathrm{~N}^{0} .1 ; \mathrm{N}^{0} .2 \text { (Histories and Theories } \\
\text { of Information Design); №.3 (Ediçäo Especial } \\
- \text { P\&D 2016) }\end{array}$ & --- \\
\hline 2017 & $\begin{array}{l}\text { v. } 14 \mathrm{~N}^{0} .1 \text {; № } 2 \text { (Ediçäo Especial - } \\
\text { CIDI/CONGIC - 2017); } \mathrm{N}^{0} .3 \text { (Informaçöes } \\
\text { complexas \& Infográficos) }\end{array}$ & --- \\
\hline
\end{tabular}

Table 1: Research bases used for phases 1 and 2.

Inclusion and exclusion criteria

During phase 1 the inclusion criteria admitted for the choice of the articles took in consideration those published in its full versions or presented as posters in the stipulated research bases, as well as those that displayed the word INFOGRAPHICS. The exclusion criteria considered the articles that were outside the 
research bases, articles where only the summary had been published, and articles published in languages other than English, Portuguese, Spanish or French.

Over phase 2, having the articles already selected in phase 1 as a starting point, the inclusion criteria admitted considered the articles that presented the word NARRATIVE. The articles that did not contain this term were excluded from the analysis.

\section{Selection of Material}

In accordance to the inclusion and exclusion criteria aforementioned, the result of the selection of material in Phase 1 produced 28 articles compiled, 14 of them from the Revista InfoDesign (Table 2), 4 from the 5th CIDI Proceedings (Table 3), 4 from the 6th CIDI Proceedings (Table 4) and 6 from the 7th CIDI Proceedings (Table 5).

\begin{tabular}{|c|c|c|}
\hline \multicolumn{3}{|c|}{ Revista InfoDesign } \\
\hline Year & Authors & Title \\
\hline 2011 & - & - \\
\hline 2012 & $\begin{array}{l}\text { Juliana Carvalho, } \\
\text { Isabella Aragão }\end{array}$ & Infographics: Concept and Practice \\
\hline 2013 & $\begin{array}{l}\text { Milena Quattrer, } \\
\text { Anna Paula Silva Gouveia }\end{array}$ & $\begin{array}{l}\text { Color and Infographic: The Information Design } \\
\text { in schoolbook }\end{array}$ \\
\hline \multirow{4}{*}{2014} & $\begin{array}{l}\text { Mariana Lapolli, } \\
\text { Tarcisio Vanzin, } \\
\text { Vania R. Ulbricht }\end{array}$ & $\begin{array}{l}\text { Organization of information in infographics storytelling } \\
\text { on the web focused on the process of teaching and } \\
\text { learning }\end{array}$ \\
\hline & $\begin{array}{l}\text { Paula Couto Lopes de Araujo Faria, } \\
\text { Virginia Tiradentes Souto }\end{array}$ & $\begin{array}{l}\text { Graphic language of online infographics of Brazilian } \\
\text { government - A case study of Portal Brasil }\end{array}$ \\
\hline & $\begin{array}{l}\text { Júlia Rabetti Giannella, } \\
\text { Sandra Souza }\end{array}$ & $\begin{array}{l}\text { Design and journalistic mediation in the production } \\
\text { of infovis: presentation of an analysis model for online } \\
\text { infographics }\end{array}$ \\
\hline & $\begin{array}{l}\text { Nadia M. Leschko, } \\
\text { Vera M. M. Damazio, } \\
\text { Edna L. O. Cunha Lima, } \\
\text { Joaquim M. F. Andrade }\end{array}$ & $\begin{array}{l}\text { Graphic repercussion of the passage of the Graf } \\
\text { Zeppelin by Brazil: infographics published } \\
\text { in newspapers }\end{array}$ \\
\hline 2015 & Ricardo Cunha Lima & What are infographics in journalism? \\
\hline 2016 & $\begin{array}{l}\text { Bolivar Teston de Escobar, } \\
\text { Carla Galvão Spinillo }\end{array}$ & Visual rethoric in health infographics \\
\hline \multirow{6}{*}{2017} & $\begin{array}{l}\text { Hanna França Menezes, } \\
\text { Carla Patricia de Araújo Pereira }\end{array}$ & $\begin{array}{l}\text { Functions of color in infographic: } \\
\text { a categorization proposal applied to the analysis } \\
\text { journalistic infographics }\end{array}$ \\
\hline & $\begin{array}{l}\text { Ana Carolina de Araújo Silva, } \\
\text { Eduardo Fernando Uliana Barboza }\end{array}$ & $\begin{array}{l}\text { Multimedia infographics: interactive possibilities } \\
\text { of a new online journalistic genre }\end{array}$ \\
\hline & Mariana Lapolli & Infographics beyond objectivity \\
\hline & $\begin{array}{l}\text { Íkaro Santhiago Câmara Silva Oliveira, } \\
\text { Angelica Porto Cavalcanti de Souza, } \\
\text { Solange Galvão Coutinho, } \\
\text { Eva Rolim Miranda }\end{array}$ & $\begin{array}{l}\text { Exploring concepts - bibliographic research } \\
\text { and elaboration of an infographic about t } \\
\text { he Information Design field definitions }\end{array}$ \\
\hline & $\begin{array}{l}\text { Fabiano de Miranda, } \\
\text { Rafael de Castro Andrade }\end{array}$ & $\begin{array}{l}\text { Pensar Infografico (Thinking Infographics): } \\
\text { a proposal of introductory teaching of infographics } \\
\text { from the perspective of graphic language }\end{array}$ \\
\hline & Andresa Richetti, Liane Roldo & $\begin{array}{l}\text { Conceptual maps and glossary based } \\
\text { on terminology for informational system: } \\
\text { case of cast iron }\end{array}$ \\
\hline
\end{tabular}

Table 2: Articles selected from the Revista InfoDesign (2011- 2017) for Phase 1. 
$5^{\text {th }}$ CIDI Annals

\begin{tabular}{|l|ll}
\multicolumn{1}{|c}{ Authors } & \multicolumn{1}{c}{ Title } \\
\cline { 2 - 3 } & $\begin{array}{l}\text { Milena Quattrer, } \\
\text { Anna Paula Silva Gouveia }\end{array}$ & The use of colors in scientific divulgation infographics \\
\cline { 2 - 3 } 2011 & Uriá Fassina & $\begin{array}{l}\text { Infographics contributions to the content assimilation } \\
\text { process on typography }\end{array}$ \\
\cline { 2 - 3 } & $\begin{array}{l}\text { Helder A. T G Cardoso, } \\
\text { Luciano Adorno, } \\
\text { Richard Perassi Luiz de Sousa }\end{array}$ & $\begin{array}{l}\text { Infographics in the era of digital information: } \\
\text { interactivity applied in e-readers. }\end{array}$ \\
\cline { 2 - 3 } & $\begin{array}{l}\text { Tânia L.K. da Silva, } \\
\text { Eduardo Cardoso, } \\
\text { Fabiano V. Scherer, } \\
\text { Ricardo M. Costa }\end{array}$ & $\begin{array}{l}\text { The infographics as a teaching resource on Design } \\
\text { of Information Systems and Communication }\end{array}$ \\
& &
\end{tabular}

Table 3: Articles selected from the 5th CIDI Proceedings for Phase 1.

\section{$6^{\text {th }}$ CIDI Annals}

\begin{tabular}{|c|c|c|}
\hline Year & Authors & Title \\
\hline \multirow{4}{*}{2013} & $\begin{array}{l}\text { Rafael de Castro Andrade, } \\
\text { Carla Galvão Spinillo }\end{array}$ & $\begin{array}{l}\text { Interactive and animated journalistic infographics: } \\
\text { analytic study about infographics health }\end{array}$ \\
\hline & $\begin{array}{l}\text { Glenda Gomes Cabral, } \\
\text { João Paulo Soares da Silva }\end{array}$ & $\begin{array}{l}\text { Infographics: A complementary way and fun to teach } \\
\text { scientific methodology for designers. }\end{array}$ \\
\hline & $\begin{array}{l}\text { Marcos Antonio de Lima Filho, } \\
\text { Hans da Nóbrega Waechter }\end{array}$ & $\begin{array}{l}\text { The design of an interactive infographic for tablet and } \\
\text { the need for new models of design }\end{array}$ \\
\hline & Ary Moraes & $\begin{array}{l}\text { The visible and invisible in journalistic infographics: } \\
\text { A reflection from the Gombrich notion of schema } \\
\text { and representation }\end{array}$ \\
\hline
\end{tabular}

Table 4: Articles selected from the 6th CIDI Proceedings for Phase 1.

\section{$7^{\text {th }}$ CIDI Annals}

\begin{tabular}{|c|c|c|}
\hline Year & Authors & Title \\
\hline \multirow{6}{*}{2015} & $\begin{array}{l}\text { Bruna Ciafrei Rinaldi, } \\
\text { Cassia Leticia Carrara } \\
\text { Domiciano }\end{array}$ & $\begin{array}{l}\text { Infographics: Trends in editorial design from the } \\
\text { magazine Superinteressante }\end{array}$ \\
\hline & $\begin{array}{l}\text { Gabriele M. S. Santos, } \\
\text { Silvio B. Campello, } \\
\text { Solange G. Coutinho }\end{array}$ & $\begin{array}{l}\text { Variables for analyzing interactive infographics: } \\
\text { a descriptive study of educational artefacts } \\
\text { for secondary school }\end{array}$ \\
\hline & Carla Cristina da Costa & $\begin{array}{l}\text { A teaching method to develop infographics based } \\
\text { on visual thinking and design thinking }\end{array}$ \\
\hline & $\begin{array}{l}\text { Rafael de Castro Andrade, } \\
\text { Carla Galvão Spinillo }\end{array}$ & $\begin{array}{l}\text { Understanding in animated and interactive journalistic } \\
\text { health infographics }\end{array}$ \\
\hline & $\begin{array}{l}\text { Ricardo Cunha Lima, } \\
\text { Rafael de Castro Andrade, } \\
\text { André Monat, } \\
\text { Carla Galvão Spinillo }\end{array}$ & $\begin{array}{l}\text { The adaptation of journalistic infographics: } \\
\text { the relationship between on-line and printed versions }\end{array}$ \\
\hline & $\begin{array}{l}\text { Daniel Nogueira, } \\
\text { Vera Lúcia Nojima, } \\
\text { Frederico Braida }\end{array}$ & $\begin{array}{l}\text { Rethoric of design: visual discourse and persuation } \\
\text { in the production of infographics }\end{array}$ \\
\hline
\end{tabular}


On Phase 2, starting from the articles previously selected on the first phase, the adopted cut considered solely the articles which contained the word NARRATIVE, reducing the corpus for analysis to 15 articles, 7 of them from Revista InfoDesign (Table 6), 1 from the 5th CIDI Proceedings, 2 from the 6th CIDI Proceedings and 5 from the 7th CIDI Proceedings, as seen in Table 7.

\section{Content Analysis}

On Phase 1 the analysis of content considered three aspects:

- The objective - in order to verify what is being studied;

- The methodology - we sought to map the approaches used and/or examine how the authors carried out the research;

- The results found - observe if the research succeeded in achieving the proposed objectives or if the theme demands further research.

The analysis of content during Phase 2 considered how the authors made use of the term narrative in the articles.

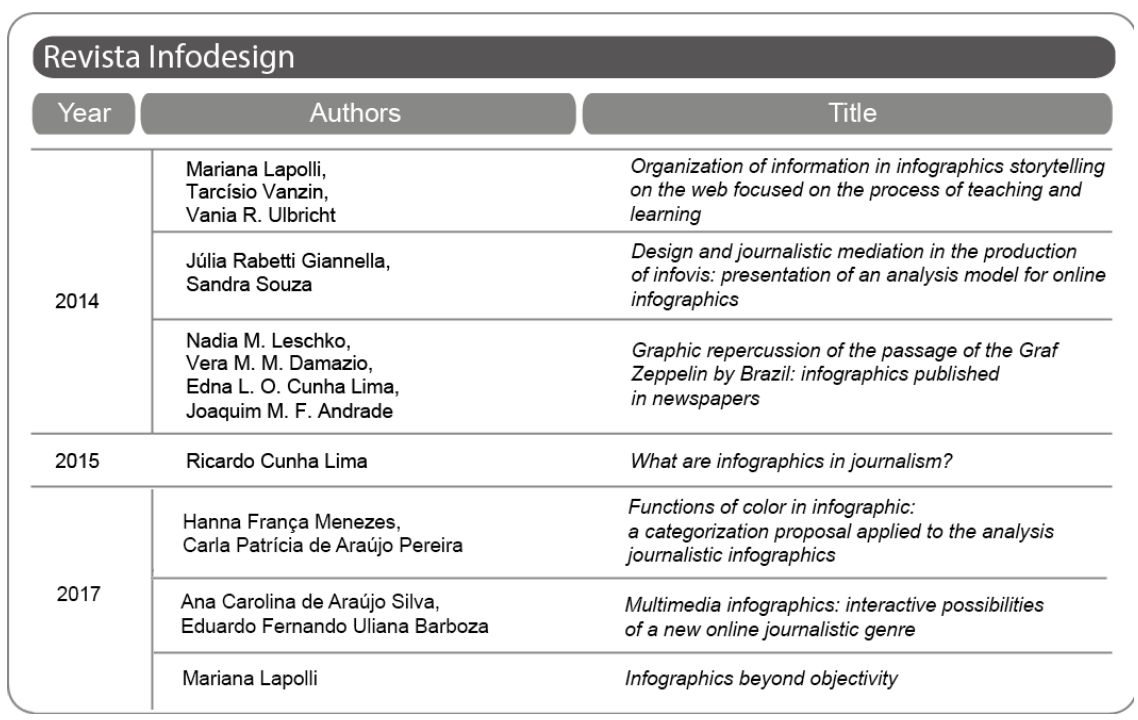

Table 6: Articles selected from Revista InfoDesign for Phase 2. 


\begin{tabular}{|c|c|c|}
\hline \multicolumn{3}{|c|}{$5^{\text {th }}$ CIDI Annals } \\
\hline Year & Authors & Title \\
\hline 2011 & $\begin{array}{l}\text { Helder A. T G Cardoso, } \\
\text { Luciano Adorno, } \\
\text { Richard Perassi Luiz de Sousa }\end{array}$ & $\begin{array}{l}\text { Infographics in the era of digital information: } \\
\text { interactivity applied in e-readers. }\end{array}$ \\
\hline \multicolumn{3}{|c|}{$6^{\text {th }}$ CIDI Annals } \\
\hline Year & Authors & Title \\
\hline \multirow{2}{*}{2013} & $\begin{array}{l}\text { Rafael de Castro Andrade, } \\
\text { Carla Galvão Spinillo }\end{array}$ & $\begin{array}{l}\text { Interactive and animated journalistic infographics: } \\
\text { analytic study about infographics health }\end{array}$ \\
\hline & Ary Moraes & $\begin{array}{l}\text { The visible and invisible in journalistic infographics: } \\
\text { A reflection from the Gombrich notion of schema } \\
\text { and representation }\end{array}$ \\
\hline \multicolumn{3}{|c|}{$7^{\text {th }}$ CIDI Annals } \\
\hline Year & Authors & Title \\
\hline \multirow{5}{*}{2015} & $\begin{array}{l}\text { Bruna Ciafrei Rinaldi, } \\
\text { Cassia Leticia Carrara Domiciano }\end{array}$ & $\begin{array}{l}\text { Infographics: Trends in editorial design from the } \\
\text { magazine Superinteressante }\end{array}$ \\
\hline & Carla Cristina da Costa & $\begin{array}{l}\text { A teaching method to develop infographics based } \\
\text { on visual thinking and design thinking }\end{array}$ \\
\hline & $\begin{array}{l}\text { Rafael de Castro Andrade, } \\
\text { Carla Galvão Spinillo }\end{array}$ & $\begin{array}{l}\text { Understanding in animated and interactive journalistic } \\
\text { health infographics }\end{array}$ \\
\hline & $\begin{array}{l}\text { Ricardo Cunha Lima, } \\
\text { Rafael de Castro Andrade, } \\
\text { André Monat, } \\
\text { Carla Galvão Spinillo }\end{array}$ & $\begin{array}{l}\text { The adaptation of journalistic infographics: } \\
\text { the relationship between on-line and printed versions }\end{array}$ \\
\hline & $\begin{array}{l}\text { Daniel Nogueira, } \\
\text { Vera Lúcia Nojima, } \\
\text { Frederico Braida }\end{array}$ & $\begin{array}{l}\text { Rethoric of design: visual discourse and persuation } \\
\text { in the production of infographics }\end{array}$ \\
\hline
\end{tabular}

Table 7: Articles selected from the CIDI Proceedings for Phase 2.

\section{RESULTS}

Concerning the use of the word Infographic, we noted a multitude of terms used, among which we can cite: Infographics, digital infographics, multimedia Infographics, journalistic Infographics, Animated and interactive journalistic Infographics, Infographic narratives, Infovis, Infographic and multimedia Infographic. This diversity found in the articles is aligned with the thinking of Ribas (2005) and Lucas (2011) regarding the issue of there being a lack of consensus in the use of the word infographic. We can see, therefore, that this variety may be a reflex of what the literature shows.

The extensive amount of terms available causes the reader to assume that there are different definitions. However, as we examined the articles, we noticed that of the 15 studies analyzed, 4 of them used as its parameter to define infographic what Lima (2009) proposes, 1 author presents its definition stemming from 
another article, which uses Lima as a reference. In addition to these, 3 articles did not define the term infographic, 3 put forward definitions but did not mention the author and 4 provided a definition based on several authors, amongst which, Lima (2009).

As we identified that many articles use Lima (2009) as a basis, we were able to notice an indicator that the authors of the articles made an attempt at using a definition which was closer to their area, since Lima proposes his concept having as a starting point authors from the field of Design, or even that there is a specific channelling regarding the choice and use of the term. In addition to this, noticing that a few authors did not define what an infographic is, or that they did not present the reference for the definition, reveals that there may be some difficulty regarding the theme.

What is more, we detected that the term journalistic infographics occur in 5 articles, which can be an indicator of converge with the area of Communication, since it is possible for this field to be already taking steps towards the construction or definition of the term for its area, if we take into consideration the references in the article by Ribas (2005) and the doctorate thesis by Lucas(2011), in which, among other things, the concept of Infographics is discussed.

It is also noted the use of the terms digital infographics and multimedia infographics, as seen in distinct articles, where digital infographics is defined as "uma forma de comunicação visual informativa, que usa de meios audiovisuais para a otimização da transmissão da informação, de modo que a mensagem seja facilmente entendida pelo usuário" (Cardoso, Adorno and Sousa, 2011, p. 1) 11 $^{11}$ and multimedia infographics, which according to Silva and Barboza (2017, p. 345), would be an informative cyber journalistic genre, but that "também proporciona a interpretação dos fatos e, em muitos casos, de forma dialógica, por ser essencialmente interativo" 12 .

Faced with the absence of a consensus for the term infographics, what can we say about the terms cited above? Would they be the same type of infographics? The conceptual questions do not seem to have such simple answers since, according to Abreu (2013, p.12) digital or multimedia infographics would be the same

11 "A type of informative visual communication, which makes use of audio-visual means to optimize the conveying of information, in such a way that the user easily understands the message."

12 "It also fosters the interpretation of the facts and, often, in a dialogic manner, since it is essentially interactive." 
thing, differing from "su hermana pequeña, la infografía tradicional"13 through the incorporation of audio-visual resources, or even photographs, maps, graphs, moving images, sounds, in a single product.

It can be observed, therefore, that even before such diversity (of terms and definitions) it is necessary to find parameters for the use of the word and its meaning, so that it is possible to create some uniformity when the topic is dealt within the realm of Design, since the absence of a common definition only hinders, even more, the understanding of an object of study, in addition to allowing for a wide range of interpretations, since the Infographic comes very close to other forms of representation that make use of text and image.

On the use of the term narrative, before we begin our remarks, we would like to clarify that we believe that the objective of the analyzed articles was not to discuss narrative. We do not intend to criticize any article or author regarding the way they used this word in their texts. Our view on them seeks only to understand, within Information Design, how the term narrative is being used in the articles that also deal with infographics.

Having said that, we noticed that the articles presented the use of the word narrative in different ways, among which we have: infographic narratives, visual narratives, non-linear complex graphic narratives, sequential narrative, narrative visualizations, journalistic narratives, digital narrative, interactive narrative and multimedia narrative. We could not find in the articles a definition for these ter$\mathrm{ms}$, which leaves the reader free to create their understanding, since, in the literature presented here, we could not find such definitions either.

To exemplify, we cut some excerpts from articles that cite the term. They are:

Nas narrativas infográficas, caracterizadas pela associação de imagens e textos simples e objetivos, as informações são organizadas de maneira que o intérprete possa visualizar aquilo que é mais importante (Lapolli; Vanzin and Ulbricht, 2014, p. 40, grifo nosso). ${ }^{14}$

Juntos, os dois gradientes indicam resultados entre forças que um mesmo dispositivo infovis exerce para explanar sequências de informação, segundo narrativas e discursos jornalístico-editoriais, e propiciar ao usuário a exploração do conteúdo a partir de percursos mais autônomos, sempre, no entan-

13 "Its little sister, the traditional infographics."

14 "In the infographic narratives, characterized by the association of simple and objective images and texts, the information is organized is such way that the reviewer can visualize that which is more important) (Lapolli; Vanzin and Ulbricht, 2014, p. 40, our emphasis)." 
to, dentro de limites preestabelecidos pelos produtores da informação (Gianella and Sousa, 2014, p. 314, grifo nosso). ${ }^{15}$

Em um contexto de transformação constante das tecnologias e, consequentemente, das narrativas jornalísticas, a infografia multimídia apresenta-se mais que uma possibilidade complementar de informação. Trata-se de uma narrativa e um gênero completamente novo, independente, com características próprias e com grande potencial para atender as demandas de um novo leitor/consumidor de notícia, menos interessado em ser somente informado e mais propenso a participar da construção da notícia (Siva and Barboza, 2017, p. 351, grifo nosso). ${ }^{16}$

In the first two excerpts, it is possible to notice that the term narrative can be interpreted in different ways. In the first example we can consider the narrative as a story, or as Bal (1997) puts it, as a text in which someone tells a story in a specific medium, in this case, using texts and images. In the second example, however, the term narrative can be referring to journalistic narrative (which we did not contemplate in our definitions) or it can also be taken as in agreement with Trask's (2004) concept, which states that the narrative is a text that tells a story, but that it differs from other texts because it narrates a series of connected events, real or fictitious, in a mostly orderly fashion, in this case, following the specificities of the journalistic-editorial discourse. In the third excerpt, the concept of narrative comes close to the one that Reis and Lopes (1988) define for the narrative while wording, as the act of reporting, differing from the meaning ascribed to the previous excerpts. Here, the multimedia infographics would not only be a complement to the information but a new way of describing the events, "independent and with specific characteristics."

In another example, it would also be possible to use the term narrative associated to what Greimas e Courtés (2013) state, since in examples of infographics

15 "Together, the two gradients indicate results between forces that a single device infovis wields to explain sequences of information, according to journalism-editorial narratives and discourse, and to foster for the user the exploring of content from more autonomous paths, always, however, within limits pre-established by the producers of the information (Gianella and Sousa, 2014, p. 314, our emphasis)."

16 "In a context of constant transformation of the technologies and, consequently, of the journalistic narratives, multimedia infographics presents itself as more than a complementary alternative of information. It is a brand-new narrative and genre, independent, with specific characteristics and great potential for meeting the demands of a new reader / consumer of news (Silva and Barboza, 2017, p. 351, our emphasis).” 
presented in the article it is possible to see characters in action (Rinaldi and Domiciano, 2015, p. 1067). In the article by Rinaldi and Domiciano (2015) it is striking that the objective is to analyze the editorial design of the infographics, starting from the concept of transmedia narrative, where, however, the narrative itself is not analyzed in the article.

In another case, we could associate the concept of the narrative according to Aumont (2012) who defines his concept within the field of narrative film. As Moraes (2014) does not present an image of the infographic in his article, we assume that they may have been created from film language, since the author comments about the narrative's organization, which in this case, may have followed the rationale of film narrative.

No segundo caso, as representações aparecem combinadas à perspectivas produzidas a partir de técnicas de representação variadas, em escalas distintas e dispostas fora da lógica sequencial da narrativa, usando, portanto, sintaxe própria. Neste grupo, cujo caso mais agudo é o do trabalho publicado pelo jornal Daily Mail, estão aqueles publicados pelos jornais Aamulehti, The Independent, New York Post, La Prensa Grafica, Kleine Zeitung, El Universal, El País, Ekstra Bladet, Daily Express, Dagens Nyheter, Aujourd'hui em France e ABC. Este grupo pode ser identificado como o dos infográficos "comprometidos" - aqueles cujo caráter de confiabilidade acaba comprometido pela lógica peculiar que adotam, pela falta e coerência visual (expressa na paleta de cores, proporções etc.) que manifestam, ou ainda pela resistência dos críticos aos clichês oriundos do cinema de ação utilizados na narrativa visual que desenvolvem (Moraes, 2014, p. 7, grifo nosso). ${ }^{17}$

17 "In the second case, the representations appear combined to perspectives produced from different representation techniques, in distinct scales and arranged differently from the sequential logic of the narrative, using, therefore, its syntax. In this group, whose most poignant case is the one of the works published by the Daily Mail newspaper, are the ones published by the newspapers Aamulehti, The Independent, New York Post, La Prensa Grafica, Kleine Zeitung, El Universal, El País, Ekstra Bladet, Daily Express, Dagens Nyheter, Aujourd'hui en France and ABC. This group can be identified as the one with the "compromised" infographics - those whose reliability is compromised by the peculiar rationale adopted, for the lack of visual coherence (expressed in the color palette, proportions, etc.) that they exhibit, or even by the resistance of the critics to the clichés deriving from action movies used in the visual narrative that they develop. (MORAES, 2014, p. 7, our emphasis).” 
We also observed that some articles used the term narrative in the sense of story, and that, in this case, very close to the one Trask (2004) defines. Perhaps this proximity is founded in what Lankow, Ritchie and Crooks (2012, p. 21) put:

Narrative an approach to information design that seeks to guide the viewers through a selected set of information that tells a story. This is best used for infographics that communicate value judgments and are designed to leave the viewers with a specific message to take away.

It is possible that this is the general idea concerning narrative that many designers adopt, the one where it tells a story, and despite it not being clear in their texts, there is a consensus that this idea extends when the term is used. However, as the use of the word narrative appears in different contexts, it is difficult to accurately associate all the meanings assigned to it. Hence, it would not be interesting for the reader to look up the definitions in order to be able to understand the meaning of a term within a specific context. Herman, Jahn and Ryan (2005) in their Routledge Encyclopedia of Narrative Theory point out that:

However, the very predominance of narrative as a focus of interest across multiple disciplines makes it imperative for scholars, teachers, and students to have access to a comprehensive reference resource - one that cuts across disciplinary specialisations to provide information about the core concepts, categories, distinctions, and technical nomenclatures that have grown up around the study of narrative in all of its guises.

We can see that the interest for the studies about narrative is on the rise in several subjects, including the field of Design. Moreover, as the subjects try to find their place inside this study, it is necessary for the Design also to define its concepts and nomenclatures so that the researchers in the area can standardize the understanding about the term.

Thus, we can conclude that the results for both the research on narrative and the examination of the term infographics, point towards a struggle to relate the literature with what is being published, since the diversity of terms and concepts found to hinder the comprehension of the term regarding the area and, consequently, the creation of some consistency in the thinking within the field.

\section{CONCLUSIONS}

One of the first observations of the scenario examined is that the theme of infographics has been gaining space in the research within the field of Information Design. Progressively, more and more papers have been published, being related to and researched with diverse themes. 
With the examination of the theme distribution in which the infographics currently related, it was possible to observe that the articles dealt with the issues of graphic aspects (not that these are not important), but they did not analyze more closely how the narrative is used, in the infographic, to convey information, or even, which issues concerning narrative the designer must observe, know about, think of, when creating an infographic.

If we consider the narrative from the viewpoint of Bal (1997) and Gancho (2006), where the narrative text tells a story, and also, from the perspective of Greimas and Courtés (2013), where the characters perform actions in the story, in a time sequence as proposed by Prince (1982), we could ask: who are the characters? Which do they experience the facts? At what time? In what place? We could even ask: is it possible that when we associate the term narrative to what we consider to be an infographic, we are contemplating telling a story, or just informing the reader in a less complex way? These are questions that still need more profound reflections so that we can reach an agreement about what we should take into consideration as a narrative in the context employed within Information Design.

Apparently the proposal set forward here has no intention to immediately determine an author to use as basis for the definition of the term narrative, but we hope that new reflections emerge concerning the conceptual issues in the field and the breadth of significations that may affect the comprehension of content, since we cannot just use a term expecting that everyone understands it in the same way. If there is a consensus within the area it is because we have already established the parameters for the understanding of this term, but which are they? The same happens when it comes to the use of the word infographics, for, if there are no difficulties to its comprehension within the realm of Design, it is because its definition has already reached an agreement amongst designers.

As we could see, the term narrative is too broad and is part of many subjects, hence, independent of the object, to make use of this term within any area, it is necessary to define parameters that will guide the discussions. What we can see in the field of Design is that there is no consensus concerning what a narrative applied to infographics is. The standardization in the use of the term would make the understanding more comfortable, and maybe, it would facilitate an understanding of the concept of narrative. To clearly understand the medium, how it works, if there are differences between the printed and digital infographic, are issues that directly interfere with the understanding of the narrative.

Thus, we can say that other studies are necessary, to look deeper into the issue of narrative alongside Information Design and infographics because there is no precise definition regarding it. These studies will also help the Design to choose an area to anchor itself or even to establish its parameters when using the terms analyzed here. 


\section{REFERENCES}

Abreu, A. A. (2013). Del ideograma a la infografía digital. El periodista sabe proponer infografías, $2^{\circ}$ - Cuadernos Artesanos de Comunicación, 46. Tenerife, Espanha.

Aumont, J. (2012). A estética do filme (9nd ed.). Campinas, SP: Papirus.

Aumont, J., \& Marie, M. (2003). Dicionário teórico e crítico de cinema. Campinas, SP: Papirus.

Bal, M. (1997). Narratology: Introduction to the Theory of Narrative (2nd ed.). University of Toronto Press Incorporated.

Cardoso, H. A. T. G, Adorno, L., \& Sousa, R. P. L. (2011). Infografia na era da informação digital: a interatividade aplicada nos e-readers. Anais do $5^{\circ}$ Congresso Internacional de Design da Informação/Proceedings of the 5th Information Design International Conference. Florianopólis, SC, Brazil.

Gancho, C. V. (2006). Como analisar narrativas (9nd ed.). São Paulo: Ática.

Giannella, J. R., \& Souza, S. (2014). Design e tratamento jornalístico na produção de infovis: apresentação de um modelo para análise de infográficos on-line. InfoDesign - Revista Brasileira de Design da Informação / Brazilian Journal of Information Design. 11(3), 305-319.

Greimas, A. J., \& Courtés, J. (2013). Dicionário de semiótica (2nd ed.). São Paulo: Contexto.

Herman, D., Jahn, M., \& Ryan, M.-L. (2005). Routledge Encyclopedia of Narrative Theory. London and New York: Routledge.

Lankow, J., Ritchie, J., \& Crooks, R. (2012). Infographics The power of visual storytelling. John Wiley \& Sons, Inc. Hoboken, New Jersey.

Lapolli, M., Vanzin, T., \& Ulbricht, V. R. (2014). Organização da informação em narrativas infográficas na web voltadas para o processo de ensino-aprendizagem. InfoDesign - Revista Brasileira de Design da Informação / Brazilian Journal of Information Design. 11(1), 36-49.

Lucas, R. J. L. (2011). 'Show, Don't Tell' a infografia como forma gráfico-visual específica: da construção do conceito à construção de sentido (Tese de doutorado). Programa de Pós-graduação em Comunicação, Universidade Federal de Pernambuco. Recife, PE, Brasil.

Lima, R. (2009). Análise da infografia jornalística (Dissertação de Mestrado). Escola Superior de Desenho Industrial da Universidade do Estado do Rio de Janeiro - ESDI/ UERJ, Rio de Janeiro, RJ, Brasil.

Moraes, A. (2014). The visible and invisible in journalistic infographics: A reflection from the Gombrich notion of schema and representation. Proceedings of the 6th Information Design International Conference, 5th InfoDesign, 6th CONGIC. 1 (2), 1460-1469.

Prince, G. (1982). Narratology: The form and Functioning of Narrative. Janua Linguarum. Series Maior 108. Berlin. 
Rajamanickam, V. (2005). Infographics seminar handout. Retrieved from: http://www. schrockguide.net/uploads/3/9/2/2/392267/infographic_handout.pdf

Reis, A. C. S., \& Lopes, A. C. M. (1988). Dicionário de teoria da narrativa. São Paulo: Ática.

Ribas, B. M. (2005). Ser Infográfico - Apropriações e Limites do Conceito de Infografia no Campo do Jornalismo. III Encontro Nacional de Pesquisadores em Jornalismo SBPJor. Florianópolis, SC, Brasil. Retrieved from: http://www.facom.ufba.br/jol/ pdf/2005_ribas_sbpjor_florianopolis_serinfografico.pdf.

Rinaldi, B. C., \& Domiciano, C. L. C. (2015). Infografia: tendências no design editorial a partir da revista Superinteressante. Anais do 7o Congresso Internacional de Design da Informação/Proceedings of the 7th Information Design International Conference. São Paulo, SP, Brasil. 2 (2), 1062-1071.

Silva, A. C. A., \& Barbosa, E. F. U. (2017). Infografia multimídia: possibilidades interativas de um novo gênero ciberjornalístico. InfoDesign - Revista Brasileira de Design da Informação / Brazilian Journal of Information Design. 14 (3), 340-352.

Trask, R. L. (2004). Dicionário de linguagem e lingüística (2nd ed.) São Paulo: Contexto.

\section{REFERENCES FROM REVISTA INFODESIGN AND THE CIDI ANNALS}

Anais do $5^{\circ}$ Congresso Internacional de Design da Informação/Proceedings of the 5 th Information Design International Conference. (2011). Florianopólis, SC, Brasil.

Coutinho, S. G., Moura, M., Campello, S. B., Cadena, R. A., \& Almeida, S. (Orgs.) (2014). Proceedings of the 6th Information Design International Conference, 5th InfoDesign, 6th CONGIC. 1 (2). São Paulo, SP, Brasil.

InfoDesign - Revista Brasileira de Design da Informação - Brazilian Journal of Information Design. (2012). 9 (3). São Paulo, SP, Brasil.

InfoDesign - Revista Brasileira de Design da Informação - Brazilian Journal of Information Design. (2013) 10 (3). São Paulo, SP, Brasil.

InfoDesign - Revista Brasileira de Design da Informação - Brazilian Journal of Information Design. (2014). 11 (1 e 3). São Paulo, SP, Brasil.

InfoDesign - Revista Brasileira de Design da Informação - Brazilian Journal of Information Design. (2015) 12 (1). São Paulo, SP, Brasil.

InfoDesign - Revista Brasileira de Design da Informação - Brazilian Journal of Information Design. (2016) 13 (2). São Paulo, SP, Brasil.

InfoDesign - Revista Brasileira de Design da Informação - Brazilian Journal of Information Design. (2017) 14 (3). São Paulo, SP, Brasil.

Spinillo, C. G., Fadel L. M., Souto V. T., Silva T. B. P., \& Camara R. J. (Eds) (2015). Anais do $7^{\circ}$ Congresso Internacional de Design da Informação/Proceedings of the 7 th Information Design International Conference. 2 (2). São Paulo, SP, Brasil. 
